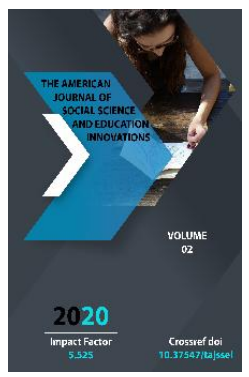

\title{
Democratic Advisement Section Convenience And Intellectual Connection Demand Amidst Indonesian Inexperienced Grownup Community
}

\author{
Ihshan Andangsari \\ Division Of Psychology, Bina Nusantara University, Indonesia
}

Journal Website:

http://usajournalshub.c

om/index,php/tajssei

Copyright: Original

content from this work

may be used under the

terms of the creative

commons attributes

4.0 licence.

\section{ABSTRACT}

The wide-spread utilization of online democratic advisement destinations has started numerous mental issues and exploration around the world. A novel wonder has appeared in which individuals depend on Facebook to fulfill their connection demand. It is one of the inherently mental requirements that presents for the duration of a life expectancy. The current examination explored the connection between connection style and democratic advisement site convenience. The outcome demonstrated that connection style contributed essentially to the degree of web-based media convenience. It likewise brought up that the connection style recognized essentially amidst dynamic and non-dynamic clients. Future exploration and ramifications of the investigation were talked about.

\section{KEYWORDS}

Connection, Facebook, Twitter, Inexperienced grown-ups, Social media, Indonesian,.

\section{INTRODUCTION}

Indonesia gets one of the best five Facebook

clients known to mankind. There are 64 million clients of Facebook that originate from Indonesia. The nation has a wellgrowing market for innovative gadgets. According to 
that, Facebook continues expanding their support of be more available through cell phone especially for Indonesian market.In Indonesia, Facebook was utilized for different purposes from simply killing opportunity to offering pundits to the administration when it raised a fuel cost. Imprint Zuckerberg's online media item has brought a few issues up in the society,e.g.,rape cases that start from talking in Facebook, posting improper pictures, offending others through posting unforgiving words in their dividers, and following. There were various examinations that were led to research Facebook convenience, however there was none any investigation to writers' information that was done to take a gander at the advisement between connection styles and Facebook utilization in Indonesian populace. Facebook has altered the way traditonal indonesians associate and fabricate a relationship with others. Indonesians who are notable for keeping customary values,e.g. eye to eye cooperation as a respectful structure for a first time correspondence, started to leave the qualities with the rise of innovation, for example, Facebook. Becaconvenience of that, examining Facebook and connection styles in Indonesia is a commendable exploration that can be a premise to take a gander at how the general public changed by embracing innovation. Facebook has changed the manner in which individuals impart, fabricate a relationship, express feeling, and do self-introduction. The current examination further took a gander at the association between connection styles of Indonesian and the method of using Facebook as the most becoming mechanical media on the planet.

\section{METHODS}

\section{Member Characteristics}

The current examination selected sound members with no mental issues. They ought to have remained in Jakarta as a metropolitan territory for over a year, which was thought to be sufficient opportunity to make them to be mixed into a metropolitan way of life, which is indistinguishable from innovation. Also, they ought to have Facebook and Twitter accounts before rounding out surveys. There were 169 members: 57 ladies and 112 men.

\section{Testing Procedure}

The current example was enrolled with arbitrary examining method and every one of them were college understudies of BINUS University, Indonesia, from different resources. They were drawn closer by research associates. Should they consent to partake in the examination; they were given an educated assent.

\section{MEASURES}

\section{Relationship Style Questionnaire (RSQ)}

Relationship Style Questionnaire (Griffin, D. and Bartholomew, 1994) was made an interpretation of and adjusted into Indonesian setting. In view of pilot study that was led, out of 30 things accessible in the poll, there were just 17 things that were utilized in the investigation becaconvenience of unwavering quality issues. The scale ranges from 1 (Not by any stretch of the imagination) to 4 (Very much likely). A portion of the inquiries are as per the following: "I stress to be harmed in the event that I get excessively close with others", "I feel entirely great when I don't genuinely join with others", and "It is difficult for me to confide in others". The poll surveyed four kinds of connection: Secure, simple to be genuinely close with others and agreeable if there is one is subject to him, not stress a lot 
over being autonomous. Dreadful, one feels hard to get genuinely close with others and hard to confide in others. Nervousness (distracted), one demands to draw near with others, yet he feels that individuals discover hard to draw near with him. Feeling awkward without cozy relationship. Avoidant (Dismissing), being agreeable without connection to other people, having cozy relationship, and want to not having others being reliant on him. This sort of individual feels free and independent.

\section{Democratic advisement Site Engagement Scale (DASES)}

The creators built DASES and did a pilot study a few times to take a gander at its unwavering quality and legitimacy esteems. The DASES estimated the long range democratic advisement site convenience by zeroing in on support of utilizing Facebook and Twitter, "I generally update my status either in Facebook or Twitter ordinary" and "I oftentimes give remarks on others' status either in Facebook or Twitter", not by the recurrence of utilizing Facebook,e.g., "How frequently do you sign in to your Facebook and Twitter every day". The scale comprised of 12 things ( $1=$ Not by any stretch of the imagination, $4=$ Very much likely). The scale likewise asked the most utilized devices to get to democratic advisement destinations, for example, Blackberry, iPhone, and Personal PC.

\section{Examination Design}

The current investigation utilized review strategy in which the surveys were dispersed amidst BINUS University understudies and gathered following a few days. They were approached to finish an educated agree preceding rounding out surveys and giving individual data. They were free not to give any response to any scrutinize that they felt excessively close to home. The interest in the investigation was carefully willfully with no impact on their scholarly issue. The members rounded out the surveys inside 15-20 minutes. They reserved an option to pull back themselves from interest at whenever. Subsequent to finishing the surveys, they were expressed gratitude toward and given a little badge of appreciation.

\section{DISCUSSION}

Corresponding to that, in any case, there is none investigation demonstrated whether the expanding number of connections that were made in Facebook will really be tried. Future examination should take a gander at how much the expanding number of cooperations in Facebook would affect disconnected circumstance, particularly amidst individuals with tension connection. Ought to there is a positive outcome, Facebook can turn into a "helpful signifies" for individuals with tension connection considering putting their trust on themselves and building relationship with others. Hopefully, it might lead them to the way of secure connection.

\section{CONCLUSION}

The current investigation has a few impediments regarding unbalance number of dynamic and non-dynamic members. Such condition may have added to non-critical distinction amidst dynamic and non-dynamic clients concerning a few connection styles: secure, dread, and excconvenience. Likewise, decreasing a few things of RSQ may have influenced some dependability and legitimacy esteems somewhat. Since all members were college understudies, the current examination can't be summed up to different populaces. 
Future exploration ought to incorporate more different members from various foundation and populaces. Considering social impacts can be considered on the grounds that better places may put diverse incentive on the significance of web and Facebook. Using more thorough scales in evaluating connection and democratic advisement webpage conduct can give a superior comprehension of how the connection collaborates with online social conduct. Foreseeing of what amount making correspondences through Facebook and Twitter can be realized in disconnected circumstance will be a productive exploration in seeing better online conduct.

\section{REFERENCES}

1. Waders, L., and kicker, S. (1997). Grownup connection style, relational correspondence capability, and social help. 9(5), 479-489.

2. Pastry specialist, L. R., and Oswald, D. L. (2010). Timidity and online democratic advisement administrations. Diary of Social and Personal Relationships, 27(7), 873-889.

3. Grazella, M. (2013, ). Facebook has $64 \mathrm{~m}$ dynamic indonesian clients. The Jakarta Post. 